DOI: https://doi.org/10.32653/CH153412-434

Абдулагатов Заид Магомедович,

к.филос.н., заведующий отделом социологии

Институт истории, археологии и этнографии

Дагестанский федеральный исследовательский центр РАН, Махачкала, Россия zaid48@mail.ru

\title{
ЗАРУБЕЖНОЕ ИСЛАМСКОЕ ОБРАЗОВАНИЕ КАК ФАКТОР РАДИКАЛИЗАЦИИ ИСЛАМСКОГО СОЗНАНИЯ МУСУЛЬМАН РОССИИ (НА ПРИМЕРЕ РЕСПУБЛИКИ ДАГЕСТАН)
}

\begin{abstract}
Аннотация. Проблемы религиозного экстремизма и терроризма в регионах России имеют свои внутренние и внешние факторы. Большое число российских политиков, светских ученых, исламских лидеров считает зарубежное исламское образование одним из значимых внешних факторов радикализации исламского сознания в России. В российском общественном сознании имеет место и противоположная точка зрения. В статье поставлена цель выявить позитивные и негативные стороны влияния зарубежного исламского образования на религиозное сознание российских мусульман в контексте исламских конфессиональных традиций в Республике Дагестан. В частности ставится задача выяснить, насколько оправдан вывод о том, что зарубежное исламское образование формирует у российских мусульман радикальное исламское сознание. Методика исследования главным образом основывается на социологическом опросе среди дагестанских мусульман, обучавшихся в зарубежных исламских учебных заведениях, у частных лиц. Кроме того использованы исторические сведения о влиянии зарубежного исламского образования на религиозное поведение еще в досоветский период российской истории.

В статье автор показал, что зарубежное образование было проблемой для российского государства еще в досоветский период его истории: северокавказские мусульмане возвращались из зарубежья с мыслями «опасными для российской государственности». На основе данных социологического опроса мусульман Дагестана, прошедших обучение за рубежом в XXI в., выявлено, что около трети из них возвратились на родину с салафитским конфессиональным сознанием. Это экстремальность сознания, которая противоречит господствующей в республике суфийской исламской традиции, в перспективе способная к протестной радикально салафитской деятельности в регионе.

Автор приходит к выводу, что в сложившейся ситуации желательно вести пропаганду «благонадежных» зарубежных образовательных центров, проводить активную работу по организации направления российских мусульман в эти центры, вести демократичный, в рамках закона, контроль за самостоятельно выезжающими.

Ключевые слова: зарубежное исламское образование; салафизм; суфизм; экстремизм; ислам; мусульмане; Дагестан; Россия.
\end{abstract}

(C) 3.М. Абдулагатов, 2019

(C) Дагестанский федеральный исследовательский центр РАН, 2019

@ C Creative Commons Attribution 4.0 International License 
DOI: https://doi.org/10.32653/CH153412-434

Zaid M. Abdulagatov, PhD (Philosophy), Head of Department of Sociology

Institute of History, Archeology and Ethnography

Dagestan Federal Research Centre of RAS, Makhachkala, Russia

zaid48@mail.ru

\title{
FOREIGN ISLAMIC EDUCATION AS A FACTOR OF RADICALIZATION OF RUSSIAN MUSLIMS (ON THE CASE OF THE REPUBLIC OF DAGESTAN)
}

\begin{abstract}
Issues of religious extremism and terrorism in regions of Russia carry both internal and external factors. A number of Russian politics, secular scholars, Islamic religious leaders consider foreign Islamic education as one of the significant external factors of radicalization of the Muslims of Russia. There also exists a contrary view.

The article aims to reveal positive and negative impacts of the foreign Islamic education on the minds of the Russian Muslims in the context of Islamic confessional traditions of Dagestan; in particular, to identify whether the conclusion about such an impact is justified.

Our research methods are mainly based on sociological survey among Dagestan Muslims, who took courses in foreign Islamic institutions, or privately. In addition to that, historical data on the impact of the foreign Islamic education on religious conduct in the Russian pre-soviet period has been used.

The author proves that foreign education was a problematic issue for the Russian government in the pre-soviet period: the North-Caucasian Muslims would allegedly return from abroad with "potentially dangerous to the Russian sovereignty" ideas.

Basing on the sociological survey of the Dagestan Muslims, who had taken courses abroad, it was revealed that almost a third of them returned home with Salafist ideas. Such extremity of ideas contradicts the dominant Sufi religious tradition of Dagestan, and is likely to create a radical Salafist activity in the region.

In conclusion, the author advices to promote "trustworthy" foreign institutions, to carry out extensive work on turning Russian Muslims towards said institutions, to monitor, within the law and democratic principles, those, who depart the country on their own.

Keywords: foreign Islamic education; Salafism; Sufism; extremism; Islam; Muslims; Dagestan;
\end{abstract} Russia. 


\section{Введение}

Актуальность темы исследования связана с тем, что, несмотря на некоторое снижение числа террористических актов и других показателей экстремистской деятельности на Северном Кавказе, вопросы экстремизма и терроризма продолжают волновать российское государство и российскую общественность. Наиболее слабым звеном в решении этой, появившейся почти тридцать лет назад, проблемы является отсутствие действенной, поддерживаемой как властью, так и обществом идеологии противодействия. Активность академического сообщества в этом направлении действенных результатов не дает, поскольку идеология противодействия и профилактики этих негативных явлений имеет в основном религиозный характер. Как выразился один из представителей академической науки, на каждого «ваххабита» проведена одна научная конференция, но результатов не видно. Есть сермяжная правда в этом высказывании: власть не стремится на деле использовать результаты научных, в особенности социологических, исследований экстремизма и терроризма. Более того, власть, в частности в Дагестане, активно игнорирует отдельные важные результаты этих исследований, навязывая исследователям свои политические установки. Например, с одной стороны ученым даются указания, что нет религиозного экстремизма, с другой же, принимается «антиваххабитский» закон, который действует в Дагестане и поныне. Или же, приближая к себе отдельные течения ислама и называя их «истинным» исламом, государство неосторожно вторгается в область богословия. Одновременно оно не уделяет должного внимания проблемам школьного, светского воспитания, социальным проблемам молодежи, о которых многократно говорят исследователи явлений экстремизма и терроризма.

Одним из источников формирования религиозно-экстремистского сознания мусульман России считается зарубежное исламское образование. Вопрос о зарубежном исламском образовании оказался сложным как для официального ислама в России, так и для российского государства. В 2009 г., реагируя на запросы религиозных и светских лидеров Северного Кавказа, Президент РФ Д.А. Медведев высказался так: «...контроль за выезжающими. Думаю, что это правильная постановка вопроса. Контроль должен быть обязательно...» ${ }^{1}$. Как будет показано в тексте, данная проблема в России все еще не решена.

Объектом исследования являются молодые мусульмане Дагестана, получавшие исламское образование за пределами России. Предмет исследования - состояние исламского сознания этой группы мусульман. Мы ставим перед собой цель определить экстремальные составляющие религиозного сознания обучавшихся исламским наукам за рубежом, выявить проблемы зарубежного исламского образования для российского 
государства и общества. Новизна проведенного исследования связана с использованием в анализе характера влияния зарубежного образования мусульман Дагестана понятия «экстремальность сознания». Это понятие в социологическом контексте впервые было использовано Чупровым В.И. и ЗубокЮ.А.Поих мнению, «становлениесубъектности молодеживпроцессе выполнения ею своих социальных функций - воспроизводственной и инновационной - сопряжено с преодолением как внутренних, так и внешних противоречий. Это способствует формированию экстремальных типов ее сознания и поведения как социально-групповых сущностных характеристик... В условиях социальных потрясений, неопределенности она приобретает крайний, преимущественно спонтанный характер, рискуя перерасти в экстремистские настроения»[9, с. 147-148]. Нельзя сказать, что здесь дано четкое и исчерпывающее определение этого понятия. Нет критериев экстремальности сознания. Каковы опосредствующие социальные звенья между экстремальностью сознания и экстремистскими настроениями? Не ясно, за всяким ли экстремальным типом поведения стоит экстремист. Тем не менее, использование понятия «экстремальность сознания» важно по ряду причин. Во-первых, изучение экстремизма и терроризма часто проводится на стадии их завершенности, когда человек уже совершил деяние, запрещенное законом. Основная масса академических исследований проблемы имеет именно такой характер: исследуется экстремист, террорист. В то же время, наиболее важной задачей является профилактика экстремизма и терроризма. Экстремальность сознания может стать одним из основных понятий системы анализа и профилактики этих негативных явлений.

В данной статье автор использует понятие экстремальности сознания, в том числе и религиозного, как крайность, которая проявляет себя в рамках закона. Это крайность, способная иметь свое нежелательное, с точки зрения интересов государства и общества, развитие в направлении практики насильственного экстремизма, терроризма. Экстремальное сознание - это основа экстремистского и террористического поведения. В ходе социологического опроса индикаторами экстремальности исламского сознания были: а) обвинение в неверии (такфир): оценка радикальных салафитов «истинными» мусульманами, суфиев - отошедшими от ислама; б) интерес респондента к зарубежному исламскому образованию, как дающему «истинные знания» об исламе; в) определение живущего в шафиитском окружении респондента своей конфессиональной идентичности, как ханбалита или вообще как безмазхабного; г) утверждение, что мусульманин должен следовать законам государства, если они не противоречат Шариату; д) положительное отношение к радикальным салафитам. Этот список может быть без труда дополнен. Например, таким же индикатором может служить отношение респондента к дагестанцам, участвующим в военных 
действиях на стороне ИГИЛ ${ }^{2}$, как к настоящим мусульманам. Экстремальность сознания есть наличие таких факторов сознания, которые не являются проявлениями экстремизма и за которые человек не обязан отвечать по закону. Но, будучи руководством к действию, они порождают явления экстремизма и терроризма.

Новизна исследования связана и с проведением социологического опроса среди обучавшихся исламским наукам. Опрос был основным методом исследования в достижении поставленной цели. Данный подход к проблеме зарубежного образования открывает новые стороны этого явления. Он позволяет конкретизировать причины мусульманского экстремистского поведения в регионе. Опрос проводился по формализованной анкете, которая прошла соответствующее обсуждение в Отделе социологии Института ИИАЭ ДНЦ РАН. В то же время автор использовал данные статистики экстремизма и терроризма в России, в частности в Дагестане. В тексте использованы экспертные оценки ситуации, высказанные известными дагестанскими религиоведами.

В ходе исследования использованы публикации в СМИ, в которых активно обсуждаются проблемы зарубежного исламского образования мусульман России.

Автор счел необходимым сделать в тексте небольшой экскурс в историю вопроса с целью получить ответ на вопрос, является ли зарубежное образование источником радикальных настроений мусульман России, появившимся в конце $\mathrm{XX}$ века, или оно имеет более глубокие исторические корни.

Полученные социологическим опросом результаты подтверждают, что зарубежное исламское образование является одним из факторов радикализации исламского сознания дагестанцев.

\section{Особенности современной ситуации проявлений религиозного экстремизма и терроризма в регионе}

Несмотря на то, что вооруженный конфликт на Северном Кавказе после известных событий конца XX и начала XXI вв. заметно стихает, это относительное затишье может иметь временный характер. Есть факты, которые дают основание таким выводам.

Во-первых, по данным Министерства обороны РФ, в ходе операций в Сирии было ликвидировано 4500 боевиков из России и стран СНГ [1, с.11]. Глава ФСБ РФ Александр Бортников заявил, что в Сирии, только по подтвержденным данным, на стороне ИГИЛ” и других отрядов воюют свыше 4 тысяч дагестанцев ${ }^{3}$. Этнолог А.А. Ярлыкапов считает, что таковых в Сирии не меньше 5 тысяч4.

2 Террористическая организация, запрещенная в РФ.

3 Алиев Ш. Размен позиций // Черновик. 21.10.2016.

4 Тлисова Ф. Эксперты: «репрессивная» политика Кремля толкает тысячи людей в ряды ИГИЛ [Электронный pecypc] www.Golos-ameriki.ru/a/russia-isis-dagestan/3238957.html. (Дата обращения: 23.10.2016). 
В российских регионах, в частности в Дагестане, остались многочисленные близкие родственники уничтоженных и ныне продолжающих воевать на стороне ИГИЛ. Нашему обществу еще предстоит переварить неизбежное возвращение многочисленных сирот и вдов этой войны в российские регионы. Нет уверенности в том, что они со временем не станут потенциальными источниками развития экстремальности сознания и экстремистского поведения в регионе. Возможно, они образуют новые спящие волны радикализации исламского сознания в отдельных регионах России.

Во-вторых, есть статистика экстремизма по списку организаций и физических лиц, включенных в «Перечень организаций и физических лиц, в отношении которых имеются сведения об их причастности к экстремистской деятельности или терроризму на основании подпунктов 1-3 пункта статьи 2.1 статьи 6 Федерального закона от 07.08.2001 № 115-Ф3 "О противодействии легализации (отмыванию) доходов, полученных преступным путем, и финансированию терроризма"». Эти списки составляются Росфинмониторингом. Из всех опубликованных списков за 2013-16 гг. автором были проанализированы наиболее значимые по исламской активности пять субъектов РФ: Дагестан, Чечня, Ингушетия, Кабардино-Балкария, Татарстан. Бросается в глаза значительное превышение числа вошедших в Перечень от Дагестана - 32,6 \%, почти треть от российского списка (Чеченская Республика - 8,7 \%; Кабардино-Балкарская Республика $-5,4$ \%; Республика Ингушетия - 1,4 \%; Республика Татарстан - 1,1 \%) ${ }^{5}$. Статистика экстремизма после 2016 года не дает оснований считать, что экстремистская деятельность дагестанцев пошла на спад. Она скорее изменила формы своего проявления. Так, по данным Росфинмониторинга, дагестанцев в одном из списков причастных к экстремистской деятельности и терроризму, опубликованном в конце 2018 г., оказалось $24,1 \%{ }^{6}$. В списке, опубликованном в начале 2019 года, их было уже $38,3 \% 7$.

Перечень показывает иные конфигурации экстремизма и терроризма в $\mathrm{Pe}-$ спублике. Это не просто бандитизм и случайные выходки «заблудших», как часто говорят, молодых людей. Это хорошо организованная, продуманная деятельность, ставящая перед собой религиозные цели. Он же показывает, что имеющие место утверждения о спаде экстремизма и терроризма в РД, не имеют оснований.

B-третьих, следует обратить внимание на то обстоятельство, что сохраняется высокий уровень экстремальности религиозного сознания части мусульманского населения. Это подтверждается не только информацией, которая дается Росфинмониторингом, но и данными социологических опросов в Дагестане. По данным социологического опроса в республике, 64,0 \% опрошенных заявили, что не следует соблюдать законы государства, если они противоречат вере.

5 Перечень дополнен // Российская газета. 15 нояб. 2013 г.; 15 янв. 2014.; 27 апр. 2015 г.; 20 июля 2015 г.; 21 авг. 2015 г.; 14 сент. 2015 г.; 19 окт. 2015 г.; 17 нояб. 2015 г.; 14 марта 2016 г.; 6 апр. 2016 г.; 18 мая 2016 г.; 14 окт. 2016 г.

6 Перечень дополнен // Российская газета. 19 сент. 2018 г.

7 Перечень дополнен // Российская газета. 11 янв. 2019 г. 
Наиболее жестко против законов государства настроена не просто молодежь, а ее младшая группа «от 15 до 20 лет». Приведенный выше показатель у нее равен 70,4 \% («не соблюдать закон, если он противоречит вере»). На вопрос «Могли бы Вы по каким либо причинам оказаться в рядах воюющих на стороне ИГИЛ?», 3,5 \% опрошенной молодежи отвечает «Да». Среди лиц с религиозным образованием таковых оказалось 10,3 \% (со светским образованием - 2,8 \%). Лишь 72,3 \% опрошенных уверенно говорят «Нет». Ответившие «Нет» и затруднившиеся с ответом на вопрос составляют довольно большую группу, чтобы быть уверенным в стабильности общественной жизни в республике.

В-четвертых, социально-экономическая ситуация в республике остается сложной. Например, если по России в целом безработица в апреле 2019 г. была равна 4,9\%, то в Северо-Кавказском федеральном округе она была самой высокой по России и составляла $11,5 \%$, а в Дагестане $-14,1 \%{ }^{8}$. Среди молодежи Дагестана этот показатель выше. В то же время, по данным социологического опроса, на первом месте среди причин экстремизма и терроризма в республике население указывает нерешенность социальных проблем молодежи.

В Москве показатель безработицы равен 1,3 \%. В действительности, в Дагестане безработица выше официально заявленной. Немалая часть населения просто не регистрируется в Центрах занятости как безработные. В 2017 г. безработица в СКФО, в том числе и в Дагестане, была ниже9. Многие годы средняя зарплата дагестанцев была самой низкой в Российской Федерации. И сегодня она остается на уровне аутсайдеров российских регионов по этому показателю. Средняя зарплата дагестанских учителей общеобразовательных школ, которые ведут воспитательную работу по противодействию экстремизму и терроризму, в 2018 г. была равна минимальному размеру оплаты труда (МРОТ) в регионе -11163 руб., тогда как на сегодня средняя зарплата в Дагестане равна 25160 руб. ${ }^{10}$.

Все это говорит о том, что социальные факторы, стимулирующие протестные настроения считать преодоленными, ликвидированными еще рано. Силовое подавление не имеет ничего общего с преодолением экстремальности сознания как проявления идеологии экстремизма и терроризма. Уже много лет мы наблюдаем отсутствие четко обозначенной светской идеологии в противодействии экстремизму и терроризму, чрезмерно высокую роль силовых методов в решении проблем экстремизма.

Это касается, прежде всего, необходимости решения множества социальных проблем, особенно молодежи, особенно в таких регионах как Дагестан, которых экономисты называют депрессивными. Бюджет РД на 2019-2020 гг. на 75

8 Занятость и безработица в Российской Федерации в апреле 2019 года//http://www.gks.ru/bgd/ free/bo4_03/Isswww.exe/Stg/do4/96.htm. (Дата обращения: 15.07.2019).

9 Занятость и безработица в Российской Федерации в сентябре 2017 года // http://www.gks.ru/ bgd/free/Bo4_03/Isswww.exe/Stg/do3/216.htm (Дата обращения: 29.07.2017.)

10 Зарплаты в России//https://visasam.ru/russia/rabotavrf/zarplaty-v-rossii.html (Дата обращения: 17.07.2019.) 
\% дотируется федеральным центром ${ }^{11}$. Эта ситуация на фоне чудовищных размеров коррупции в республике остается неизменной в течение многих лет.

Существующая в регионах религиозная оппозиция традиционному исламу все еще сохраняется, а где-то и усиливается.

Мировоззренческая растерянность системы школьного образования и воспитания сосуществует с чрезмерно высокой ролью религиозной социализации молодежи в отдельных регионах РФ.

Это, и многое другое, есть то, что касается внутренних факторов, способствующих экстремальности сознания, как следствие - ее радикализации. Но есть и внешние факторы, такие как деятельность ИГИЛ, пропаганда идей радикального ислама через Интернет, деятельность зарубежных исламских организаций в РФ и др. ${ }^{12}$ Среди них особое место занимают вопросы экстремизма и терроризма, связанные с особенностями зарубежного исламского образования российских мусульман.

\section{Из истории зарубежного исламского образования дагестанцев}

Вопрос о зарубежном исламском образовании не является новой проблемой российского государства, возникшей на стыке двух веков - XX и XXI. Еще в XVII в. для совершенствования знаний в Хиджаз, Египет, Йемен, а возможно и в Крым, Азербайджан, Иран, Хорасан, Среднюю Азию, Османскую Турцию, отправлялся известный на мусульманском Востоке ученый из дагестанского села Кудутль (ныне Гергебильского района РД) Мухаммад б. Муса б. Ахмад ал Кудуки ар-Ругуджа ал-Авари ад-Дагестани ${ }^{13}$. Важно заметить, что богословское творчество Мухаммада ал-Кудуки не вписывалось в сложившуюся систему суннитстких масхабов. Ал-Кудуки писал: «Я отказывался от последования толкам всю свою жизнь и отдал предпочтение «Книге» (Корану. - A.3.) перед сподвижниками» [2, с. 583]. Большое влияние зарубежное исламское образование на дагестанцев оказало через «школу Кудутлинского», из которой вышла целая плеяда видных исламских ученых Дагестана. Характеризуя одного из них - Барка Кади из Какамахи, известный дагестанский ученый Али Каяев (Замир Али) пишет, что он был «одним из тех, кто первым выступил против тарикатского учения и мюридизма» [3, с. 65].

Еще в досоветский период обучавшихся в зарубежных исламских учебных заведениях характеризовали как салафитов-ваххабитов. Дагестанский просветитель и религиозный лидер Али Каяев в 1905-1907 гг. учился исламским наукам в Аль-Азхаре (Каир). Он тесно общался с египетскими реформаторами, в

11 Республика Дагестан. Закон о республиканском бюджете Дагестан на 2018 г. и на плановый период 2019 и 2020 годов // www. minfinrd.ru/file/download/5196 (Дата обращения: 16.07.2019).

12 В Дагестане в 2013-14 гг. активную работу проводил Всемирный союз мусульманских ученых (ВСMУ) во главе с его генеральных секретарем Мухаддином аль-Карадаги. В настоящее время деятельность ВСМУ запрещена на территории РФ.

13 Шихсаидов А.Р. Ал-Кудуки // Ислам на территории бывшей российской империи. М., 2006. С. $222-223$. 
том числе и с Рашидом Рида. По мнению лидеров дагестанского суфизма, в том числе ныне покойного авторитетнейшего шейха Саида Афанди Чиркейского, Али Каяев является первым дагестанским ваххабитом $\left[4\right.$, с. 99 ${ }^{14}$.

В действительности, салафитское влияние зарубежного исламского образования на дагестанское исламское сознание имело место до Али Каяева. Сам Али Каяев считал, что распространение религиозного свободомыслия в Дагестане явилось результатом чтения книг йеменского ученого Салиха ${ }^{15}$. Достоверные сведения о дагестанских богословах, которые реально занимались иджтихадом, приводятся известным востоковедом И.Ю. Крачковским. В его работе «Дагестан и Йемен» на основе различных исторических источников показывается, что интерес к личности муджтахида Салиха Йеменского в Дагестане имел место в течение длительного исторического времени. Доказательность, отсутствие полного доверия к традиции (таклиду), суфийской причастности к сокровенному, выражение своего мнения по разным мазхабам Салихом Йеменским говорит о том, что в Дагестане с XVII в. с помощью его книг распространялись идеи иджтихада. Более того, идеи рационализма, заложенные в трудах Салиха Йеменского, активно переносились в Дагестан и отдельными учеными, одним из которых был Мухаммад ал-Кудуки (1652-1717) [2, с. 580; 5, с. 48-53].

Об опасности зарубежного исламского образовательного влияния на российскую государственность еще в начале XX в. писал кавказский наместник, великий князь Николай Николаевич императору Николаю II: «...Недостатки в постановке учебного дела приводят к тому, что русские мусульмане, предназначающие себя для духовной деятельности, стремятся в Заграничные учебные заведения, где воспринимают часто взгляды и убеждения, опасные для русской государственности ${ }^{16}$.

Приведенные выше сведения показывают, что имеющие в религиозной и научной среде объяснения причин оттока мусульман России в зарубежные образовательные центры советским атеистическим периодом истории не соответствуют действительности.

Дагестанцы едут в другие страны за другими исламскими знаниями, которых не было ни в Российской империи, ни в Советской России, которых нет и в постсоветской России. Во-первых, в российском исламе мало внимания обращается исламской философии. В современном дагестанском исламе исламской философии, можно сказать, вообще нет. Это следствие традиции, основы которой заложил Абу Хамид аль-Газали (1058-1111). В книге «Тахафут аль-фаласифа» (Самоопровержение философов») аль-Газали отрицал необходимость философии в религиозном познании. Дагестанские мусульмане чтят его на-

14 Нуридинов Р. Ваххабизм - вирус в исламе // «Ассалам». № 20, 1998.

15 Каяев А. Биографии дагестанскихученых арабистов. Рукопись на турецком языке // Рукописный фонд Института ИАЭ ДНЦ РАН. Ф. 25. оп. 1, д. № 1. С. 4.

16 Доклад великого князя Николая Николаевича императору Николаю II о политическом положении на Кавказе, 23 сентября 1916 г. // Кавказ и Российская империя: проекты, идеи, иллюзии и реальность. Начало XIX - начало XX в. Сборник документов. Изд. журнала «Звезда». С.-Петербург. 2005. С. 549. 
следие. Во-вторых, в российском исламе господствуют ханафитский и шафиитский мазхабы, которые не могут вобрать в себе все богатство мусульманских наук. B-третьих, господствующее в Дагестане суфийское направление в принципе не может давать исламские знания, которые основаны на салафитских идеях о «чистом» исламе.

В зарубежном образовании дагестанцы ищут «чистый» ислам. Данные опроса, приведенные в тексте, подтверждают это. Пока мусульманское образование в России не может давать таких знаний. Даже если это было бы возможно с привлечением зарубежных специалистов, по соображениям религиозно-политическим эти знания представителями официального ислама распространяться в Дагестане не будут.

\section{Российские мусульмане в зарубежных образовательных сетях}

По имеющимся публикациям о зарубежном исламском образовании, в основном российские мусульмане учатся в Египте, Королевстве Саудовская Аравия (КСА), Сирии, Ираке, Турции, Тунисе, Алжире, Узбекистане (Бухара), Иордании, Судане, Бахрейне, Малайзии, Марокко. В ходе опроса выявилось, что дагестанцы имеют более широкий круг своих исламских образовательных интересов в его географическом выражении: Грузия (Аджария), Азербайджан, Алжир, Египет, Индия, Индонезия, Иран, Йемен, Киргизия, Китай, Малайзия, Пакистан, Саудовская Аравия, Судан, Сирия, Узбекистан, Тунис, Турция, - всего 18 государств. Нет оснований считать, что этот список полностью описывает географию стран зарубежного образования дагестанцев. Дагестанских мусульман государства исламского образования по данным социологического опроса наиболее интересуют в следующем порядке: Сирия - 28,6\%, Египет - 16,3 \%, Турция - 14,3\%, Малайзия - 6,1\%.

Одним из наиболее популярных исламских учебных заведений является имеющий древние корни (основан в 972 г.) исламский университет Аль-Азхар (Каир).

Известный дагестанский салафит Абас Кебедов считает, что «практически 90 процентов исламского знания вышло из Аль-Азхара, Египта»17. Аль-Азхар сегодня - гигантский религиозный и образовательный комплекс, где обучаются более 120 тыс. чел., из них иностранцев - 25 тыс. Количество российских студентов, по разным данным, колеблется от 1000 до 1500 чел. В основном это выходцы из Северного Кавказа. По данным одного из студентов Аль-Азхара Амина Магомедова, сегодня в университете на разных курсах учатся до 200 выходцев из Дагестана18. В 1996 г. в зарубежных образовательных центрах обучались 1500 дагестанцев [6, с. 5]. Известный дагестанский религиовед К.М.

17 Абас Кебедов: Я вижу новую эру - исламскую // http:ansar.ru/person/2011/05/16/15539 (Дата обращения: 27. 11. 2013)

18 Асадулаев М. Заграница нам не поможет...// Новое дело. 5 июня 2009 г. 
Ханбабаев в беседе с автором статьи говорил о 3000 дагестанцах, выехавших за рубеж за исламскими знаниями. Считать, что в настоящее время эти показатели снизились, нет оснований.

По данным экспертных оценок и самих студентов, обучающихся в Аль-Азхаре, российская молодежь, выезжающая в Египет с целью получения мусульманского образования, неоднородна по конкретному характеру этой цели. Тех, кто настроились на долгую учебу в университете с намерением закончить его и получить диплом выпускников Аль-Азхара не так уж много ${ }^{19}$.

\section{Показатели влияния зарубежного исламского образования на проявления экстремизма и терроризма в Республике Дагестан}

По данным статистики последних лет, в возрастной структуре задержанных, осужденных, уничтоженных в ходе антитеррористических операций дагестанская молодежь (от 15 до 30 л.) обозначена в пределах от 65 до 75 \%. Коренного перелома в этом силовом противостоянии еще не произошло.

Одновременно, именно молодежь является основной возрастной группой, которая активно повышает свой мусульманский образовательный уровень, в том числе и в зарубежных исламских учебных заведениях. Средний возраст респондентов, составляющих выборку, оказался в пределах 30 лет.

По официальным данным более 400 дагестанцев прошли обучение в Аль-Азхаре (Египет). Около 40 из них уничтожены в ходе контртеррористических операций правоохранительными органами ${ }^{20}$. Очевидно, нет гарантий того, что остальные 90 \% дагестанских выпускников Аль-Азхара являются законопослушными гражданами республики.

Известные лидеры северокавказского радикального ислама Анзор Астемиров и Магомедали Вагабов, которые были кадиями «Имарата Кавказ» ${ }^{21}$, после распада Советского Союза обучались в зарубежных исламских учебных заведения ${ }^{22}$. Есть много и других представителей исламского радикализма, обучавшихся в зарубежных исламских учебных заведениях, которые вели и ведут активную экстремистскую и террористическую деятельность на Северном Кавказе. Они же были проповедниками идей активного участия дагестанцев в деятельности ИГИЛ (запрещенная в России организация). Так, Камиль Султанахмедов, получивший исламское образование за рубежом, многие годы вел проповедческую деятельность в г. Избербаш и в крупном Каякентском районе РД. Видеозапись его присяги ИГИЛ появилась в Интернете 2 июня 2015 г. $^{23}$.

19 Аль-Азхар в зоне RU. Чем живут российские студенты зарубежных исламских вузов. Интервью с редактором сайта Аль-Азхар. RU Идрисом Магомедовым. //http://www.al-azhar.ru/node/332 (Дата обращения: 15.09. 2013).

20 Аль-Азхар закрыт для россиян // Новое дело. 21 янв. 2011 г.

21 Террористическая организация, запрещенная в России.

22 Мамаев А. Еще один похороненный меч // Черновик. 27.08.2010.

23 Магомедов Р. Вместо вывода-2// Черновик. 5.06.2015. 
Нелишне заметить еще раз, что по разным оценкам в деятельности ИГИЛ участвовали от 2 до 5 тысяч дагестанцев. Как заявил в СМИ глава РД Р.Г. Абдулатипов (2013-2018 гг.), только из Унцукульского района республики в рядах ИГИЛ против правительственных войск Сирии воюют 47 дагестанцев ${ }^{24}$. Представитель руководства Унцукульского района на просьбу оказать содействие в проведении социологического опроса обучавшихся в зарубежных исламских учебных заведениях ответил: «Да, у нас их много, но опрос невозможен, все находятся в лесу!».

С началом перестроечных процессов открылась дорога зарубежным проповедникам ценностей исламского образования в России. В частности, в исламском образовательном процессе в Дагестане активно участвовали преподаватели из арабских стран. Они имели сильное влияние на формирование молодежного крыла радикального салафитского движения в дагестанском исламе. Информацию о том, как это проходило в Исламском институте им. Имама Шафии в г. Махачкала, дал автору бывший студент этого института, ныне зав. отделом восточных рукописей Института ИАЭ ДНЦ РАН Ш.Ш. Шихалиев:

«...Как правило, учебного плана, привязки к какому-либо учебнику, программе не было...У студентов, где преподавали арабы, были широкие взгляды по общим вопросам исламской цивилизации (исламская культура, история, Акыда). ... Образование преподавателей-арабов давало знания об Ибн Таймийи, разных течениях в исламе, о хадисах. Давались знания о Д. Афгани и других исламских реформаторах (М. Абдо, Р. Рида). Они обозначены в дагестанском суфийском дискурсе «распространителями зла», «заблудшими», «еретиками». ...У дагестанских преподавателей тоже хорошие знания хадисов, но они сильно привязаны к Муамалату, а у арабских - непосредственно к исламскому призыву, Акыде.

...Многие, кто учились у арабских преподавателей, приняли салафитские (ваххабитские) идеи. Одним из преподавателей - арабов был Мухаммад Хани, выпускник Аль-Азхара, хафиз (наизусть знал Коран). Кроме исламского Института им. Имама Шафии, работал также и в ДГУ, преподавал арабский язык. Он был закреплен в аспирантуру (по истории). Издал брошюру про имама Шамиля. ... Был пойман на вербовке дагестанских студентов. Часто выезжал в пионерские лагеря, проводил занятия. Остальные были гражданами Ирака, Судана, Алжира, Египта, КСА. Абузагир Мантаев, Ясин (Махач) Расулов - известные лидеры молодежного крыла дагестанских радикальных салафитов, учились в Исламском институте им. Имама Шафии, причем, они обучались в группах преподавателей-арабов...

Арабскими преподавателями была организована общественная организация (1992 г.) по реализации исламского призыва»25.

Подобное происходило во многих регионах России с мусульманским насе-

24 Работать на совесть! Ответы Главы РД Р.Г. Абдулатипова на вопросы телезрителей и журналистов // Дагестанская правда. 27 ноября 2014 г.

25 Беседа с Ш.Ш. Шихалиевым состоялось 20 июля 2012 г. 
лением. С начала 90-х годов XX в. функционировал Государственный исламский институт в Грозном, где обучались 420 студентов одновременно, а преподавателями в нем работали 12 выходцев из Судана, Иордании, Сирии и других арабских стран [7, с. 69-70]. Такие медресе появились и в Поволжье, например, Алметьевское медресе в Татарстане ${ }^{26}$. Как правило, у выпускников этих исламских учебных заведениях формировались не свойственные региональным традициям радикально салафитские взгляды.

Нередко исследователи отмечают несомненно положительные стороны зарубежного влияния на исламский образовательный процесс в России, но забывают дать полную картину этого явления. Как пишет В.О. Бобровников, несмотря на высокие статистические показатели роста современных исламских учебных заведений России, общий уровень образования упал. «Лучше было поставлено образование в открытых на саудовские деньги ваххабитских мадрасах, крупнейшая из которых, ал-Хикма (более 750 учащихся), работала с перерывами в 1991-1999 гг. в Кизилюрте» ${ }^{27}$. В то же время хорошо известно, что именно Кизилюртовский район РД был одним из центров пропаганды радикальных салафитских идей и салафитской террористической деятельности в Дагестане в 90-е годы XX в. Проблема для традиционного ислама, общества, как оказалось, и для государства, была в другом: как преподается основы мусульманского вероучения - акыда, одна из многочисленных дисциплин исламского образования. Одно из основных положений акыды - таухид (единобожие), отношение к которому является одним из главных критериев, разделяющих салафитов и суфиев. Именно это обстоятельство вызывало и вызывает особую озабоченность у представителей местного духовенства. Такую опасность в образовательной системе видело не только северокавказское духовенство, но и духовенство Поволжья. Идеи ваххабизма через легитимную систему исламского образования России, по их мнению, распространялись «не только на Северном Кавказе, но и в Пензенской, Ульяновской, Оренбургской, Свердловской областях и в Татарстане» ${ }^{28}$.

\section{Зарубежное исламское образование: pro et contra}

Было бы несправедливо, следуя по отдельным фактам опросных данных, давать однозначно отрицательные оценки влиянию зарубежного исламского образования на социальное, гражданское поведение мусульманина. Несомненно, образование в данной системе намного богаче, разнообразнее по своему влиянию на человека. Приведенные факты важны лишь в той мере, что указывают на слабые, уязвимые места в этой системе с точки зрения всеобщих, в том

\footnotetext{
26 Юсупов А.Н. Ваххабизм в Татарстане // http://tatpolit.vu/category/zvezda/2010-01-18/2518/ (Дата обращения 1.10.2013)

27 Бобровников B.O. Дагестан // Ислам на территории бывшей Российской империи. Энциклопедический словарь. М., 2006. С. 124.

28 «Единобожники» шагают по планете // Красная звезда. 5 ноября 2004 г.
} 
числе и светских, а не локально-конфессиональных интересов дагестанцев, которые в перспективе и в идеале должны развиваться в русле единых интересов российского общества и государства.

В российском обществе сложилось мнение, что зарубежное образование способствует радикализации исламского сознания мусульман. Этой оценки в основном придерживаются сторонники суфийского ислама, которые исторически являются непримиримыми противниками различных проявлений салафизма. В настоящее время именно суфийский ислам является «официальным» исламом в Республике Дагестан. В то же время вопрос о негативном влиянии всего зарубежного образования на межконфессиональные, конфессионально-государственные отношения не так очевиден. В связи с этим, одна из задач социологического исследования сводилась к выявлению того, каково влияние зарубежного исламского образования мусульман Дагестана на их социальное (религиозное) поведение.

\section{Доводы, приводимье сторонниками зарубежного ислалского образования в его заициту}

Они различны и в основном сводятся к следующему.

1. Экстремизм проявляет та молодежь, которая обучалась за рубежом, но не завершила его, не получила диплом.

2. Исламское зарубежное образование не может формировать радикальный салафизм по той причине, что правящие режимы в этих странах сами «дико боятся» экстремизма.

3. Зарубежные исламские вузы хорошо обучают богословским дисциплинам, таким как фикх (мусульманское право), Коран, хадисы и другие, но не учат особенностям просветительской работы в странах, в которые они вернутся, то есть в России, Англии, США, Казахстане и др. А это уже другое образование, не имеющее непосредственное отношения к мусульманскому образованию.

4. В самом исламе радикализма нет. Радикализм возникает в ситуациях, когда происходит перекос между пониманием ценностей светской жизни и потустороннего мира. Когда к этому миру (дунья) относятся как к ошибке бога и ищут пути выхода из него, стремясь на тот свет, появляется мотив к радикализации. Ошибочно считать, что знание культуры ислама эквивалентно пониманию специфики проблем, порождающих радикализм.

5. Запрет на зарубежное образование, в том числе и исламское, не законен. Экстремистами можно стать, не выезжая за пределы России.

6. К выпускникам зарубежных исламских вузов в Дагестане предвзятое отношение, так как зачастую они рушат стереотипы, созданные предками, основанные не на шариате, а на обычаях. Очень сложно отказаться от того, на что опирались предки, но ведь и они могли заблуждаться. То есть, дело не в зарубежном образовании, а в отношении к нему. 
7. В Дагестане имеет место мнение, что исламская образовательная система является образцовой и качественной, превосходящей зарубежные системы подобного рода. То же самое имеет место и в других республиках Северного Кавказа29. В действительности, большинство преподавателей исламских учебных заведений в Дагестане, да и во всей России, в лучшем случае являются выпускниками тех же дагестанских, российских вузов и медресе. Или же, получили свое образование, обучаясь подпольно или самостоятельно в годы советской властизо. «По уровню преподавания филиалы исламских вузов Дагестана» (52 филиала, около 3000 студентов) можно сравнить со средними медресе»[8, с. 4]. В данной позиции более категоричен этнограф А.А. Ярлыкапов, который утверждает, что «появившиеся в 1990-х гг. исламские вузы практически остаются на уровне медресе и даже мектебов»31. Зарубежное образование восполняет этот пробел.

8. Выпускники зарубежных исламских учебных заведений, в частности Королевства Саудовская Аравия (города Мекка, Медина), практически не могут быть преподавателями дагестанских исламских учебных заведений. Во-первых, они боятся обвинений в экстремизме, ваххабизме (КСА - родина ваххабизма), во-вторых, их просто не подпускают к такого рода деятельности. То есть, исламское образование в Дагестане и в России в целом изначально имеет религиозно-политическое содержание, которое усиливает имеющее место межконфессиональное противостояние.

\section{Исламское зарубежное образование как проблема для государства и общества}

Эта проблема может быть обозначена в следующем виде.

1. В разных муфтиятах, в позициях исламских лидеров России, отношение к зарубежному образованию разное, что мешает иметь единое в программной определенности содержание учебного процесса, единые нормативные требования к перечню приемлемых для россиян зарубежных исламских учебных заведений.

2. Нет определенности в данном вопросе и у светских экспертов. В субъектах РФ среди них есть как сторонники, так и противники зарубежного исламского образования.

3. Проблему контроля за выездом молодых мусульман в зарубежные исламских учебных заведения власть до сих не смогла решить. В большей степени это

29 См: Программы РИУ им. Кунта-Хаджи Кишиева не уступает ведущим вузам мусульманского мира // http://Salambek.net/forum/100 - 1709 - 1. (Дата обращения 11. 09. 2012).

зо Без автора. Проблемы и перспективы исламского образования в Дагестане // Новое дело. о9. 05. 2003.

31 Ярлыкапов А.А. Исламское образование в Дагестане: эволюция содержания //htpp:www.ethnonet.ru/etnografiya/islamskoe-obrazobanie-v-dagestane-jevoljucija/ (Дата обращения 20.11.2013). 
касается частных выездов молодых людей в зарубежные страны.

4. Механизм отправки российских студентов в исламские образовательные учреждения за рубежом не сформирован.

5. Низка эффективность сотрудничества с зарубежными исламскими учебными заведениями в деле подготовки соответствующих времени программ обучения.

6. Не существует механизма взаимного признания исламских образовательных учреждений в РФ и за рубежом, что является препятствием в аккредитации и лицензировании исламских учебных заведений РФ.

7. Отдельные муфтияты имеют «свои» исламские вузы за рубежом. Противоречия между муфтиятами усиливаются зарубежным исламским образованиem.

8. Выпускники зарубежных исламских учебных заведений имеют проблемы с трудоустройством больше, чем их сверстники, получившие образование на территории России.

9. Выпускники зарубежных исламских учебных заведений формируют в России другую исламскую культуру, противоречащую традиционной. Становление этой культуры идет конфликтно, с нарушениями закона, проявлениями экстремизма и терроризма.

10. «...Даже в известных исламских вузах «Аль-Азхар» (Каир), «Абу-Нур» (Дамаск), «Аз-Зайтун» (Тунис) дагестанский студент может столкнуться с тем, что расходится с исламскими нормами. ...Более 70 \% студентов, которые возвращаются в Россию после обучения за рубежом не способны воспринимать истинные знания об исламе... Важно чтоб Россия сама занялась подготовкой своих специалистов» ${ }^{32}$.

\section{Результаты социологических опросов}

Анализ научной и публицистической литературы по обсуждаемой проблеме показывает, что исследователями до сих пор не проведена социологическая работа по выявлению причин оттока молодежи в зарубежные исламские образовательные центры, влияния этих центров на социальное (религиозное) поведение мусульман России.

В структуре выборки молодежь представлена больше, чем старшее поколение: 54,8 \% против 45,2 \%. Это в целом соответствует активному участию молодежи, как в общих процессах исламского возрождения, так и ее доле, участвующей в деятельности НВФ. Эти данные выборки соответствуют и уровню заявленной религиозности этнических мусульман республики: молодежь - 95 \%; общее по Дагестану - 90 \% (старшее поколение - около 85 \%).

32 Максуд Садиков. Мусульманское религиозное образование в России и за рубежом. Интервью //http://www.intergax - religion.ru/islam/?act = interview\&div = 118\&domain = 3 (Дата обращения: 20.02. 2013). 


\section{Формы (типъ) зарубежного исламского образования, в которые вовлечены дагестанцы}

Важность постановки такого вопроса связана с тем, что зарубежное образование можно получить как в государственном, так и в частном образовательном учреждении, и даже у частного лица. Негативное влияние зарубежного образования на социальное (религиозное) поведение справедливо связывают и с тем, что дагестанцы нередко получают образование не в государственной системе, где есть определенные государством образовательные стандарты. Частная организация, особенно отдельное лицо, как правило, не может дать учащемуся необходимые знания не только по разнообразным светским наукам, но и богословским.

По данным опроса 48,9 \% опрошенных получали исламские знания в частном секторе. Мужчины пользуются этой формой образования больше, чем женщины (мужчины - 50,0 \%; женщины - 44,4 \%). В то же время в частном образовательном учреждении обучались 36,8 \% мужчин, у частного учителя - 13,2 \%. Ни одна из женщин у частного учителя образование не получала. В целом в государственные образовательные учреждения попадает примерно половина выезжающих на зарубежное образование (51,1 \%).

\section{Каким образом мусульмане РД попадают в зарубежные образовательные центры?}

Актуальным для России в целом в смысле противодействия экстремизму и терроризму остается вопрос о том, каким образом мусульмане попадают в зарубежный образовательный процесс. Академик Е.М. Примаков считал, что они в своем большинстве оказываются за рубежом по приглашению уже обучающихся там земляков, и, как правило, «легко попадают под влияние радикалов» ${ }^{33}$.

По данным опроса менее одной трети - 28,5 \% дагестанцев была направлена на рубежное образование Духовным управлением мусульман Дагестана (ДУМД) или какой-либо другой российской религиозной организацией. Среди мужчин таковых оказалось 22,5 \% (женщины - 53,5 \%). Немало лиц - 22,4 \% получали образование по приглашению и финансированию зарубежного учебного заведения. Максимальные показатели оказались по пункту «это была частная поездка» - 38,8 \%. Мужчины - 42,5 \%, женщины - 22,2 \%. В целом, 65 \% мужчин уезжают в другие страны с целью получения исламских знаний без ведома какой-либо российской мусульманской организации. Всего 7,5 \% мужчин-дагестанцев направляются на такого рода обучения ДУМД. В то же время именно социальная группа мужчин оказывается наиболее подверженной влиянию радикальных исламских взглядов.

33 Примаков E.M. Неотложная к решению проблема // Российская газета. Федеральный выпуск. 2012. № 5746 (76). 


\section{Образовательный уровенъ дагестанцев, өъезжающих на зарубежное исламское образование ${ }^{34}$}

Структура выборки по образованию была следующей

По светскому образованию:

Начальное (4 кл.) - 6,0 \%

Среднее (9-11 кл.) - 42,0 \%

Среднее специальное - 4,0 \%

Незаконченное высшее (после 3 курса) - 10,0 \%

Высшее - $38 \%$

Без образования $-4 \%$

По религиозному образованию:

Чтение Корана - 25,5 \%

Окончил(а) мактаб - 21,3\%

Окончил (а) медресе $-14,9 \%$

Окончил (а) исламский университет $-21,3 \%$

Без образования $-17,0$ \%

Необходимо обратить внимание на то, что группы с 4 \% не имеющих никакого светского образования, и 6 \% - с начальным образованием, попадая в частные руки, могут навсегда остаться людьми с низким светским образованием. В среднем по России не имеющим никакого светского образования считается $0,1 \%$ населения ${ }^{35}$, и это считается высоким показателем для нормальной адаптации к современной жизни.

В то же время необходимо заметить, что в исламских учебных заведениях РД доля обучающихся лиц с высшим светским образованием значительно меньше, чем у вовлеченных в зарубежное исламское образование: 8,7 \% против 38,0 \%. Кроме того, дагестанцы, отправляющиеся за исламским образованием в другие страны, намного старше тех, кто получает такое образование в республике. Это говорит о том, что большинство обучающихся за рубежом сделали самостоятельный серьезный жизненный выбор.

Исламские религиозные лидеры часто, с целью предостеречь направляющегося на зарубежное образование от экстремистской идеологии, предлагают предварительно обучить его основам традиционного ислама на родине. Не менее важно, чтобы направляющийся был подготовлен и в светском образовании, о чем религиозные лидеры не любят говорить.

Не менее ущербна структура религиозного образования выезжающих за рубеж. «Чтение Корана» $(25,5 \%)$ и полное отсутствие исламского образования (17 \%) в сумме составляют 42,5\%. Обе эти группы в лучшем случаерискуют оказаться студентами подготовительных курсов с надеждой поступить в вуз. В худшем -

34 Часть респондентов отметила по две позиции.

35 Анализ динамики и уровня образования населения //http://coolrejeram.com./ Статистическое изучение уровня образования в России. (Дата обращения: 5.12.2018). 
будут брать уроки у частных лиц, хотя первоначально им необходимо будет как-то освоить арабский язык. В любом случае надеяться на то, что эти 42,5 \% смогут за несколько лет получить высокое мусульманское образование трудно. Как считают эксперты, получение такого образования потребует от не знающих арабского языка и основ исламской религии как минимум 9 лет кропотливой работы. А это - длительная социализация в иной социокультурной среде.

Немало проблем в смысле поступления сразу в исламский университет возникнут и у группы, закончившей медресе (14,9 \%). На уровне медресе учащиеся обучаются намазу, чтению арабского текста Корана, осваивают основы грамматики арабского языка (сарф), правила чтения Корана (таджвид), основы религии. О каких-либо глубоких знаниях в дагестанских медресе говорить и не приходится. Преподаватели медресе в подавляющем большинстве не имеют соответствующей методической подготовки [10, с. 110-111; 11, с. 5].

\section{Причинъ интереса к зарубежному исламскому образованию: мнения опроченных}

Одна из главных причин привлекательности зарубежного исламского образования для дагестанцев - это «быстрое и качественное освоение арабского языка». Об этом говорят почти 6о \% ответов опрошенных. Эта позиция опережает другую - «отсутствие высококвалифицированных кадров» в дагестанских исламских учебных заведениях: 49,2 \%. Тем не менее, считать освоение арабского языка единственной определяющей причиной выезда дагестанцев на зарубежное образование было бы неверно. Арабский язык нужен не ради освоения десакрализованных ценностей, а именно ради исламских, сакральных. В этом смысле в общей выборке достаточно большие проценты получили не только проблема языка, отсутствие местных кадров, но и причины узости исламских образовательных программ в Дагестане, заключающаяся в том, что они сконцентрированы исключительно на освоении знаний о шафиитском масхабе (30,6 \%), на вопросах фикха (23,5 \%). То есть, интерес к зарубежному образованию вызван рядом причин, главные из которых по значимости можно расположить в следующем порядке: арабский язык, педагогические (образовательные) кадры, образовательные программы.

Одним из предложенных ответов на вопрос о привлекательности зарубежного образования была ее его характеристика как дающего «истинные знания» об исламе. Эта позиция была отмечена 27,1 \% опрошенных. По данным другого опроса, проведенного в исламских учебных заведениях Дагестана в 2016 г., этот показатель был равен 1,6 \%. Это говорит о том, что дагестанцы уезжают за исламскими знаниями в далекие страны не только, а может быть и не столько потому, что в республике нет условий для получения достаточных знаний, например, по суфизму, шафиитскому мазхабу. Их интересуют другие знания, которые невозможно в принципе получить в Дагестане, если даже система исламского образо- 
вания будет в республике на высоком уровне. Она имеет узко конфессиональное содержание, тогда как у немалой группы мусульман есть потребность выйти за пределы отдельного суннитского мазхаба, течения.

В исламском межконфессиональном дискурсе понятие «истинный ислам» имеет сложный и конфликтогенный характер. Салафиты и тарикатисты по-разному истолковывают ее содержание. Вопрос об «истинном» исламе является одним из дискуссионных в исламском межконфессиональном дискурсе. Он является центральным в конфликте салафизма и суфизма в современном исламе. Обвинение в неверии (такфир) в суннитском исламе проводится отрицанием суннитских мазхабов салафитами и салафизма суфиями. Ваххабизм есть одно из проявлений салафизма, зародившееся на почве ханбалитского мазхаба. Ответ на вопрос, кто из респондентов делает акцент на «истинном» исламе как о причине привлекательности зарубежного образования, связан с их ответами на конфессиональную идентичность.

\section{Конфессиональные идентичности дагестанцев, получавших исламское образование за рубежом}

Конфессиональный состав выборки социологического опроса оказался несколько смещенным в сторону салафизма по сравнению с конфессиональной структурой носителей исламского сознания в Дагестане. В исламской конфессиональной структуре Дагестана, учитывая наличие в республике ханафитов из числа ногайцев и части северных кумыков, шафиитов должно быть около 89 \%. По данным социологического опроса 2016 г. в исламских образовательных центрах Дагестана шафиитами определили себя 97,6 \% опрошенных. Среди обучавшихся за рубежом шафиитами себя, как видно по данным таблицы № 1, назвали 60,8 \% опрошенных.

Таблица № 1. Распределение ответов на вопрос: «Какой мазхаб в исламе Вы исповедуете?». Обучавшиеся в зарубежных исламских учебных заведениях. (в \%).

\begin{tabular}{|c|c|c|c|c|c|c|c|}
\hline 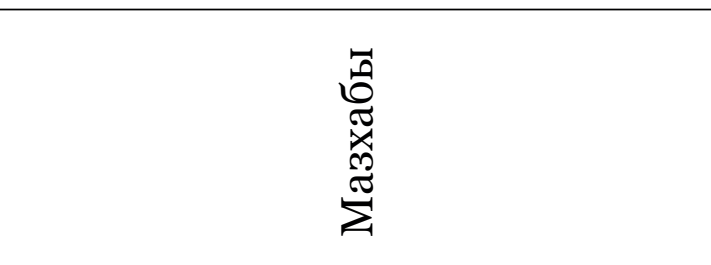 & 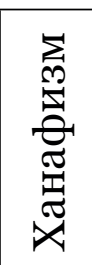 & 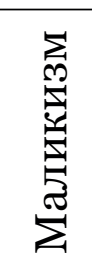 & 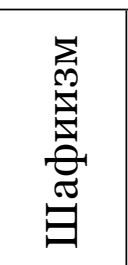 & 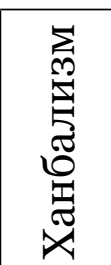 & 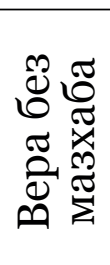 & 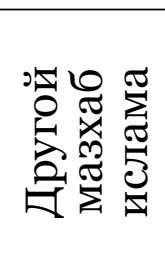 & 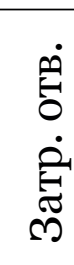 \\
\hline $\begin{array}{c}\text { Доля попавших в случайную вы- } \\
\text { борку из данного мазхаба (\%) }\end{array}$ & 5,9 & 2,0 & 60,8 & 15,7 & 15,7 & 7,8 & 0,0 \\
\hline
\end{tabular}

Салафизм выборки по данным таблицы определяется тем, что одна часть респондентов идентифицирует себя с ханбалитами - салафитским мазхабом, правым радикальным крылом которого является ваххабизм, а другая - вовсе отрицает какую-либо свою мазхабную принадлежность. Согласно точке зрения последователь- 
ных салафитов, исламская религия должна быть такой, какой она была до мазхабов, т.е. она должна быть религией праведных предков (ас-салаф ас салихун), не разделявших ислам на мазхабы. Таким образом, 31,4 \% ответов на данный вопрос можно считать имеющим салафитское содержание. Как оказалось, именно эти две группы определяли основной состав тех респондентов, которые уехали в зарубежные исламские образовательные центры в поисках знаний об «истинном» исламе.

Салафизм указанных двух групп опроса выявился в их отношении к суфиям. 57,1 \% безмасхабных считают, что суфии «заблудшие». В общей выборке так считают всего 21,7 \%. В то же время истинными мусульманами умеренных салафитов в Дагестане считают 57,1 \% безмазхабных и 85,7\% ханбалитов, тогда как среди шафиитов таковых оказалось всего 13,3\%.

Высокий салафитский потенциал зарубежного исламского образования проявляется и в ответах респондентов на вопрос: «Скажите, пожалуйста, как Вы относитесь к радикальным салафитам, или, как их называют в Дагестане - к «ваххабитам»?». Отношение респондентов к «ваххабитам» оказалось более строгим, с точки зрения признания их мусульманами, чем к «умеренным» салафитам. Тем, не менее, «хорошее отношение» к ним проявляет больше четверти «фундаменталистов». В общей выборке их оказалось 22,4 \%. В условиях многолетней активной антиваххабитской деятельности государства - в РД до сих пор действует «Закон о запрете ваххабитской и иной экстремистской деятельности в РД» (1999 г.), мощной антисалафитской деятельности доминирующего в республике тарикатского ислама, это высокий показатель салафитских настроений обучавшихся за рубежом. Если исходить из числа 3000 дагестанцев, прошедших за последние годы обучение за рубежом, то мы имели бы при репрезентативности выборки около 700 таких сторонников радикального салафизма, которые в определенных условиях могут оказаться в рядах «лесных братьев», ИГИЛ. И в этом случае, салафизм через отношение к «ваххабитам» в большей степени проявили те, кто считает себя ханбалитами или безмасхабными. «Хорошее отношение» к «ваххабизму», как к истинной религии мусульман, выразили 57,1 \% ханбалитов и столько же безмасхабных. Среди обозначавших себя шафиитами таковых оказалось всего 10,0 \%.

Среди назвавших себя шафиитами, возможность получать знания об «истинном» исламе как причину привлекательности зарубежного образования отметили 13,3 \%. Среди ханбалитов и безмасхабных этот показатель равен 28,6 \%.

Всего 10,2 \% опрошенных считают, что «мусульманин должен следовать законам государства, если даже они противоречат шариату». Зарубежное салафитское влияние в этом пункте становится очевидным, если обратить внимание на активную деятельность в России зарубежных ученых. Всемирный Совет мусульманских ученых (BCMУ) в Дагестане во главе с его генеральным секретарем, шейхом, доктором Мухаддином Али аль-Карадаги в 2013-14 гг. провел в Дагестане две богословские конференции. В материалах конференции, разделе «Позиция ислама в отношении сотрудничества со светским государством» мусульманам дается наставление: «Соблюдение законов государства обязательно, если есть четкое понимание, что они не противоречат Шариату...позитивная интеграция и соблюдение законов, 
не противоречащих установкам исламского Шариата, служение Родине, чтоб такой патриотизм не противоречил религиозной преданности в рамках достижения блага» ${ }^{6}$. В республике, где есть «антиваххабитский» закон, Мухаддин аль-Карадаги на встрече с молодыми мусульманами Дагестана говорит о том, что главная книга Мухаммада Абдель Ваххаба «Таухид» «не является экстремистской или противоречащей исламу и не призывает к убийству» 37.

\section{Основные въцоды}

1. Российские мусульмане в лице дагестанцев активно вовлечены в процессы исламского образования в зарубежных странах. Существующее в российском общественном сознании мнение, что это связано с отсутствием мусульманских образовательных учреждений в долгий период советского атеизма, не имеет объективных оснований. Зарубежное исламское образование было проблемой для российской государственности еще в досоветский период её истории.

2. Отрицание отдельными религиозными и светскими лидерами важности исламского зарубежного образования для российских мусульман не соответствует высокому уровню данного образования, которая привлекает российских мусульман. Российский мусульманин едет в далекие страны не только за высокими, но и за другими знаниями, которым в мусульманских учебных заведениях России не обучают.

3. Содержание зарубежного образования мусульман включает в себя такие составляющие, которые не вписываются в схемы традиционной исламской культуры российских мусульман. В условиях глобализации оно активно смешивает исламские традиции, имеющие различные региональные нормативности, что способствует формированию экстремальностей религиозного сознания мусульманского населения. В первую очередь это касается салафитских и радикальных салафитских идей, пропагандируемых рядом зарубежных исламских образовательных центров, о чем свидетельствуют как социальное (религиозное) поведение обучавшихся за рубежом дагестанцев, так и результаты социологического опроса в их среде.

4. Негативное отношение к зарубежному исламскому образованию формируется и по причине жесткой межконфессиональной конкуренции между официальным исламом, который представлен суфийской исламской традицией в Дагестане, и салафитами. Муфтияту РД, при всем его стремлении, не удается взять под свой контроль вопросы организации зарубежного исламского образования дагестанцев.

5. России необходим демократичный, основанный на законе, контроль за мусульманами, выезжающими в зарубежные страны с целью получения мусульманского образования. Задача состоит в том, как его организовать.

36 «Российские мусульмане: права и обязанности» // Времена. Приложение к газете «ёлдаш». 02.05.2014.

37 Материалы международной богословской конференции «Российские мусульмане: права и обязанности». Махачкала, 2014 г. С. 42. 


\section{СПИСОК ЛИТЕРАТУРЫ}

1. Сокирянская Е.Л. Можно ли предотвратить новые волны радикализации на Северном Кавказе? // Центр анализа и предотвращения конфликтов. $2019-73$ с.

2. Крачковский И.Ю. Дагестан и Йемен // Избранные сочинения. T. VI. Издательство АН СССР. М.-Л., 1960. С. 574-584.

3. Абдуллаев М.А., Меджидов Ю.В. Али Каяев. Махачкала, 1968. - 183 с.

4. Чиркейский C.A. Сокровищница благодатных знаний. Махачкала, 2010. - 469 с.

5. Абдулагатов 3.М. Истоки исламского рационализма в Дагестане // Минарет. Нижний Новгород. № 2-3.

6. Макаров Д.В. Официальный и неофициальный ислам в Дагестане. М., 2000. $-84 \mathrm{c}$.

7. Курбанов Х.T. Религиозно-политический экстремизм на Северо-восточном Кавказе. Ростов-на-Дону, 2006. - 156 с.

8. Наврузов А.Р. Исламские вузы постсоветского Дагестана в международных образовательных сетях // Ислам в современном мире: внутригосударственный и международно-политический аспекты. Нижний Новгород. 2006 г. Вып. 4. С. 55-72.

9. Чупров В.И., Зубок Ю.А. Экстремизм среди молодежи // Мониторинг общественного мнения: экономические и социальные перемены. 2009. № 1 (89). С. 146-166.

10. Ярлыкапов А.А. Современные проблемы исламского образования на Северном Кавказе // Ислам в России: взгляд из регионов. М.: Аспект Пресс. 2007. С. 103-122.

11. Ярлыкапов А.А. Исламское образование на Северном Кавказе в прошлом и настоящем// Вестник Евразии №2(21), 2003. C. $5-31$.

Статья поступила в редакцию 07.08.2019 2.

\section{REFERENCES}

1. Sokiryanskaya E.L.Can wepreventnewwaves of radicalization in the North Caucasus? [Mozhno li predotvratit' novy`e volny` radikalizaczii na Severnom Kavkaze?] Center for analysis and conflict prevention. 2019. (In Russ.)

2. Krachkovsky I.Y. Dagestan and Yemen [Dagestan i Jemen] Selected Works. Vol. VI. Publishing House of the USSR Academy of Sciences. Moscow-Leningrad, 1960: 574-584.(In Russ.)

3. Abdullaev M.A., Medzhidov Y.V. Ali Kayaev. Makhachkala. 1968.(In Russ.)

4. Chirkeysky S.A. Treasury of blessed ideas [Sokrovishhnicza blagodatny 'kh znanij]. Makhachkala, 2010. (In Russ.)

5. Abdulagatov Z.M. The origins of Islamic rationalism in Dagestan [Istoki islamskogo raczionalizma v Dagestane] Minaret. Nizhny Novgorod. № 2-3. (In Russ.)

6. Makarov D.V. Official and unofficial Islam in Dagestan [Oficzial ’ny `j i neoficzial `ny `j islam $v$ Dagestane]. Moscow, 2000. (In Russ.)

7. Kurbanov H.T. Religious and political extremismin the North-EastCaucasus [Religioznopoliticheskij e kstremizm na Severo-vostochnom Kavkaze]. Rostov-on-Don. 2006. (In Russ.)

8. Navruzov A.R. Islamic institutions of the post-Soviet Dagestan in international educational networks [Islamskie vuzy postsovetskogo Dagestanavmezhdunarodny ‘khobrazovatel `ny`kh setyakh] Islam and the modern world: domestic and international political aspects [Islam $v$ sovremennom mire: vnutrigosudarstvenny $j i$ mezhdunarodno-politicheskij aspekty]. Nizhny Novgorod. 2006. Issue 4: 55-72. (In Russ.)

9. Chuprov V.I., Zubok Y.A. Extremism among young people [Ekstremizm sredi molodezhi Monitoring of public opinion: economic and social changes [Monitoring obshchestvennogo mneniya]. 2009. № 1 (89): 146-166. (In Russ.)

10. Yarlykapov A.A. Modern issues of Islamic education in the North Caucasus [Sovremenny`e problemy`islamskogo obrazovaniya na Severnom Kavkaze] Islam in Russia: from the regions' perspective [Islam $v$ Rossii: vzglyad iz regionov]. M.: Aspect Press. 2007: 103-122. (In Russ.)

11. Yarlykapov A.A. Islamic education in the North Caucasus in the past and present [Islamskoe obrazovanie na Severnom Kavkaze v proshlom i nastoyashhem Herald of Eurasia [Vestnik Evrazii]. № 2 (21), 2003: 5-31. (In Russ.) 